\title{
Review on Graduate Program of Fisheries and Marine Sciences in Indonesia
}

\author{
ARI PURBAYANTO, ${ }^{1}$ IQBAL DJAWAD, ${ }^{2}$ AND SUBIYANTO ${ }^{3}$ \\ ${ }^{1}$ Bogor Agricultural University, Kampus IPB Darmaga, Bogor 16680 (aripy@indo.net.id), \\ ${ }^{2}$ Hasanuddin University, ${ }^{3}$ Diponegoro University
}

SUMMARY: Graduate program in fisheries and marine sciences in Indonesia is relatively new and still offered by a small numbers of the government universities. Bogor Agricultural University is the leading university, which has offered the graduate program in Fisheries Sciences starting from 1981 by launching the Aquatic Sciences Study Program for master and doctoral levels. In 1993, the graduate program in Marine Sciences and Marine Technology was then opened followed by Coastal and Marine Resource Management program. After that time, the other universities such as Hasanuddin University, Sam Ratulangi University, and Diponegoro University has also opened the program. The field study are offered by each university generally focussed on four fields of studies, i.e. the aquatic science, marine sciences and marine technology, marine and coastal resources management, and coastal management. This paper is aimed to review the graduate program of fisheries and marine sciences in Indonesia, with the Bogor Agricultural University, Diponegoro University, and Hasanuddin University as the case.

\section{KEY WORDS: Graduate program, fisheries and marine sciences, Bogor Agricultural University, Diponegoro University, Hasanuddin University}

\section{Introduction}

Graduate programs found in Indonesia are, from a structural point of view, relatively new. The program was established by the Bogor Agricultural University (IPB) in 1975 and was designated the IPB Graduate School. In 1979, the school was renamed as the Graduate Faculty. Since 1990, the Master and Doctorate programs at all major Indonesian universities have concurrently been given the name Graduate Program.

The Graduate Program in Fisheries Sciences was started in 1980 by launching Study Program of Aquatic Science at the IPB Graduate Program. Starting from September 1993 Faculty of Fisheries and Marine Sciences joint with IPB Graduate Program offered Graduate Program in Marine Sciences and Marine Technology. After that time, the other universities such as Hasanuddin University, Sam Ratulangi University, and Diponegoro University started to open the Graduate Program in Fisheries and Marine Sciences.

This paper is aimed to review the graduate program of Fisheries and Marine Sciences in Indonesia especially for the Bogor Agricultural University, Diponegoro University, and Hasanuddin University. The materials used were obtained from the universities catalog books, published information, and personal communication with the representative persons from the Graduate Programs of each university.

Academic Program and Curricula

Bogor Agricultural University as the leading university in agricultural sciences as well as fisheries sciences offers four study programs with various interest areas for master and doctoral levels (Table 1). While, Diponegoro University and Hasanuddin University still offer one study program in general field of fisheries sciences especially designed for the master level. 
Beside the regular courses program, recently IPB has launched the special classes for the executives and professionals under the study program of Marine Technology and Marine and Coastal Resource Management. These classes are conducted in each Friday evening and Saturday. The interest area of these classes is Marine and Fisheries Development Planning and Marine and Coastal Resource Management.

Table 1. Study Programs and Its Interest Areas Offered by IPB, Diponegoro University and Hasanuddin University.

\begin{tabular}{|c|c|c|c|}
\hline University & Study Program & Sub-Study Program/Interest & Level \\
\hline \multirow[t]{4}{*}{ Bogor Agric. Univ. } & Aquatic Science & $\begin{array}{l}\diamond \text { Fisheries Resource and Aquatic } \\
\text { Environment Management } \\
\diamond \text { Aquaculture }\end{array}$ & $\begin{array}{l}\text { M.Sc., Dr. } \\
\text { M.Sc., Dr. }\end{array}$ \\
\hline & Marine Technology & $\begin{array}{l}\diamond \text { Marine Living Resource Management } \\
\diamond \text { Marine and Fisheries Development } \\
\text { Planning* } \\
\diamond \text { Marine Living Resource Exploration }\end{array}$ & $\begin{array}{l}\text { M.Sc., Dr. } \\
\text { M.Sc., Dr. } \\
\text { M.Sc., Dr }\end{array}$ \\
\hline & Marine Science & $\begin{array}{l}\diamond \text { Oceanography } \\
\diamond \text { Marine Biology }\end{array}$ & $\begin{array}{l}\text { M.Sc., Dr. } \\
\text { M.Sc., Dr. }\end{array}$ \\
\hline & $\begin{array}{l}\text { Marine and Coastal- } \\
\text { Resource Management }\end{array}$ & $\begin{array}{l}\diamond \text { Marine and Coastal Resource } \\
\text { Management } \\
\diamond \text { Marine and Coastal Resource } \\
\text { Management* }\end{array}$ & $\begin{array}{l}\text { M.Sc., Dr. } \\
\text { M.Sc., Dr. }\end{array}$ \\
\hline Diponegoro Univ. & $\begin{array}{l}\text { Coastal Resource } \\
\text { Management }\end{array}$ & $\begin{array}{l}\diamond \text { Exploitation and Conservation of } \\
\text { Coastal Resource Management } \\
\diamond \text { Coastal Aquaculture Management } \\
\diamond \text { Fisheries Agro-Industry Management }\end{array}$ & $\begin{array}{l}\text { M.Sc. } \\
\text { M.Sc. } \\
\text { M.Sc. }\end{array}$ \\
\hline Hasanuddin Univ. & Agriculture Systems & $\diamond$ Fishery & M.Sc., Dr. \\
\hline
\end{tabular}

Remark: *Special class

\section{Bogor Agricultural University}

Bogor Agricultural University applies decentralization system in managing the graduate program. Here the Graduate Program holds coordinated educational programs with the tasks are to manage educational administration, set the standards of academic practice, manage collaboration and promotional activities, and service student and general administrative requirements. In respect with decentralization principles, academic activities are held by the Faculty in IPB, with Chairpersons of the Study Programs directing the educational studies.

Aquatic Science Study Program is aimed to provide the foundation for basic and applied sciences oriented toward aquatic productivity and the application of ecological principles in management of living aquatic resources. This study program has three interest areas, i.e.
Aquatic Resource Management, Aquaculture, and Fisheries Resources Management. The course for the master program is totally 41 credits during four semesters, and for the doctoral program are totally 43 credits during six semesters. There are some courses of basic sciences must be taken during the $1^{\text {st }}$ and $2^{\text {nd }}$ semester and the rests are elective courses.

The number of students registered in the Aquatic Science study program are 81 master students and 13 doctorate students. These students were whose enrolled the program in the period of 1996-2001.

Marine Technology Study Program is aimed to provide the advance knowledge of marine technology especially in marine living resources exploration and exploitation. This study program has three Sub-Study Programs i.e., Marine 
Living Resources Management, Marine Resources Exploration, and special class of Marine and Fisheries Development Planning for the executives and professionals. The courses for the master program are totally 44 credits during four semesters, and for the doctoral program are totally 47 credits during six semesters. There are some courses of basic sciences must be taken during the $1^{\text {st }}$ and $2^{\text {nd }}$ semester and the rests are elective courses.

The number of students registered in this study program are 65 master students and 33 doctorate students. These students were enrolled this program during the period of 1996-2001.

Marine Sciences Study Program is aimed to provide the advance knowledge of marine sciences especially in ocean character, and processes occurred in the ocean itself. Two study programs are offered here i.e., oceanography and marine biology. The course for the master program is totally 41 credits during four semesters, and for the doctoral program are totally 43 credits during six semesters. There are some courses of basic sciences must be taken during the $1^{\text {st }}$ and $2^{\text {nd }}$ semester and the rests are elective courses.

In total, 34 master students and 10 doctorate students were registered in this study program during the period of 1996-2001.

Coastal and Marine Resource Management Study Program is aimed to provide stakeholders/manager of coastal and marine area with science and knowledge of planning and management for coastal and marine area. There are two classes, one is regular classes and another one is a special class for the executives and professional. The course for the master program is totally 44 credits during four semesters, and for the doctoral program are totally 43 credits during six semesters. Some courses of basic sciences and principles of coastal and marine resource management must be taken during the $1^{\text {st }}$ and $2^{\text {nd }}$ semester and the rests are elective courses.

The number of students registered in this study program are 197 master students and 61 doctorate students. The students were enrolled this program during the period of 1997-2001.

\section{Diponegoro University}

Coastal Resources Management Study Program at Diponegoro University was established in 1999 based on the Decision Letter of the Director General of Higher Education, National Education Department, Republic
Indonesian Number 231/DIKTI/Kep/1999. This program is only for the master level with three concentrations: Management of Exploitation and Conservation of Coastal Resources, Management of Coastal Aquaculture, and Management of Fisheries Agro-Industry.

This study program offers a basic and advanced science, as well as planning methodology, implementation, monitoring and evaluation to comprehend the ecology and dynamic of coastal resources, particularly to improve the utilization of coastal and marine resources in sustainable manner. The aims of this study program are as follows: (1) to improve professional duty through research and development program, (2) to make achievement in the development of science, (3) to develop knowledge in the field of work, and (4) to develop science and technology for solving a problem in the community.

There is a package course program of master level with a totally $40-46$ credits during four semesters. The students graduated from nonfisheries and marine sciences program are required to take a matriculation program with special courses of fisheries, coastal, and marine sciences.

The students registered in this study program were totally 92 students with gradually increased in number from 15 students in 1999 to 48 students in 2001.

\section{Hasanuddin University}

Study program offered in Hasanuddin University is Agriculture Systems with concentration in fishery science for master and doctoral level. The aims of this program is to provide the basic and applied sciences for increasing knowledge in ecological concept, aquatic productivity, physiology of aquatic biota as the basis for valuation and solving problem in aquatic resource management and aquaculture.

The curriculum for master program required 4150 credits during four academic semesters and for doctorate program required at least 45 credits during six academic semesters. There is some package courses must be taken during the $1^{\text {st }}$ and $2^{\text {nd }}$ semesters and the others are elective courses that can be taken during $3^{\text {rd }}$ and $4^{\text {th }}$ semesters.

The students registered in the period of 1997 2001 for master level were totally 60 students. In 1997 was only 7 students entered this program then increasing by year and became double number in 2001 of 13 students. At present, no doctorate student has been registered in the field area of fishery science. 
General Academic Regulation

\section{Admission}

Any Indonesian citizen who fulfils the requirements established by each university and holds an undergraduate degree recognized by the Indonesian government is eligible to be accepted as a graduate student. Overseas applicants are required to show their competence conversing in Bahasa Indonesia and provide proof of study permit from the Ministry of National Education of Indonesia after fulfilling all academic requirements.

\section{Tuition Fee}

The tuition fee at IPB Graduate program for the domestic students is about US\$ 250 400 per semester for the master level and US $\$ 200 \sim 500$ per semester for the doctorate level. The tuition fee for foreign students is about US $\$ 1000$ per semester. At Diponegoro University and Hasanuddin University, the tuition fees ranged from US $\$ 170-175$ per semester for the domestic students.

\section{International Cooperation}

Since 1995 Bogor Agricultural University, Diponegoro University, Hasanuddin University and the other four government universities i.e., Riau University, Sam Ratulangi University, Mulawarman University, and Pattimura University have a linkage with the JSPS Core University Program with Diponegoro University as the core university in Indonesia side and Tokyo University of Fisheries as the core university in Japan side. The JSPS core university program covers some activities i.e., cooperative research, scientist exchange, international seminars and workshop, and Ph.D. scholarship program for each member university in Indonesia. The first phase of this program will be terminated in 2004 .

In 2000, Bogor Agricultural University has also signed the agreement with Tokyo University of Fisheries for the student exchange program. Under this program, in 2001 one graduate student from the Tokyo University of Fisheries has been dispatched in IPB for six months.

\section{Concluding Remarks}

Bogor Agricultural University has collaborated with other universities in managing graduate program in Agriculture Sciences including Fisheries and Marine Sciences.

The universities that have in conjunction with IPB currently holds independent status in administrating graduate program such as Hasanuddin Univ., Samratulangi Univ., etc.

JSPS Core University Program has given an opportunity for the lecturers from member universities to pursue $\mathrm{Ph} . \mathrm{D}$ degree as well as to improve their research ability through the cooperative research program. This will be an advantage to strengthen the Graduate Program in Each University.

\section{Acknowledgments}

We acknowledge to the representative persons of IPB's Graduate Program (Prof. Dr. Syafrida Manuwoto and Prof. Dr. Daniel R. Monintja), Diponegoro University, and Hasanuddin University who provided data and information that make us possible to complete this paper. 